\title{
Extrinsic Factors Impacts of Motivation on Job Commitment among the Employees of the Private Banks in Bangladesh
}

\author{
Most. Ayasha Siddiqua \\ Assistant Professor, \\ Department of Management Studies, Begum Rokeya University, Rangpur, Bangladesh
}

\begin{abstract}
The commitment of employees is an integral component of corporate survival. Studies have found that determination has a significant influence on the effective overall performance of a company. An overly optimistic worker may consider that the company's dreams and ideals may have a more powerful option to belong to the employer and show more commitment to the organization. If human assets are said to be the most outstanding property of an organization, dedicated human assets should function as an entity's strategic advantage. The commitment of workers complements overall process efficiency. Motivation, motivating employees to expend time and electricity leading to the major corporation's performance, is a crucial indicator of this dedication. Because of this reality, the relationship between encouragement and commitment is a growing hobby in knowledge. Several studies carried out on inspiration and dedication; however, studies on relations between distinct motivation and remarkable commitment focus are hardly investigated-factor evaluation, SEM, which means structural equation modeling techniques used for knowledge assessment. The impacts have demonstrated that all extrinsic components have significant and widespread employee influences. This looks at the correct amount of knowledge on the importance of extrinsic influences in enhancing employee involvement within Bangladesh's non-public commercial banks.
\end{abstract}

Keywords: extrinsic factors, Motivation, Private commercial banks, employee commitment, Bangladesh

DOI: $10.7176 /$ RHSS/11-4-01

Publication date: February $28^{\text {th }} 2021$

\subsection{INTRODUCTION}

In these days' rapidly converting company surroundings, businesses worldwide need to apply the most capacity in their human sources to stay in advance of the fierce competition and live to tell the tale inside the center of the hunt. Big corporations are constructed on the inherent fee in their human assets as prompted, and committed employees are the nearly constant organization to grow quicker than comparable aggressive agencies. A wellmotivated and dedicated workforce feels that agency costs may play a vital role inside their organization, which substantially enhances each employee's overall organizational performance (Shore, \& Martin, 1989; Meyer, Paunonen, Gellaty, Goffin, \& Jackson, 1989). Employee motivation and commitment may be very vital for an organization's fulfillment. Employees with high tiers of commitment and task involvement go on paintings in time and are typically more excellent inspired to put extra efforts. However, employees with a minor level of commitment and process involvement are least influenced and feature more great excuses and illness or transportation problems. Compared to surprisingly dedicated employees (Blau, 1986; Blau \& Boal, 1987). Employee dedication is considered a vital element since it ameliorates a friendly atmosphere within a corporation, making the total workforce enthusiastically work together to attain individual personnel' and organizational goals $(\mathrm{Col}, 2004)$. In this manner, it is virtually proper to talk approximately the dedication as an extraordinary uniting aspect that complements employees' work effectiveness. The leads of high-quality and durable organizational effects now not only via higher motivation and job involvement of employees (Meyer, Paunonen, Gellaty, Goffin, \& Jackson, 1989). the advent of a beautiful and cooperative beautiful inside an organization and uniting organization and dedicated team of employees improves the business enterprise's overall functioning, considering the importance of human resources within a business enterprise's success. The cutting-edge studies look at becoming carried out in Pakistan's banking sector. Finding the affiliation amongst three essential jobs associates three personnel behaviors, i.e., motivation, dedication, and an,d job involvement, which are considered maximum vital elements for boosting personnel' and organizational performance.

Work is an essential determinant of employee motivation, in step with numerous researchers (Bartelsman, Scarpetta \& Schivardi, 2005; Randolph, 2016). Saks (2006) measured employee motivation by supplying vital practices, namely reward and acknowledgment. Innocenti, Pilati, and Peluso (2010) expected that employee motivation in a piece area relies on how correctly a corporation motivates its employees, and one of a kind motivational sports are being finished. Heneman, Greenberger, and Strasser (1988) have assumed that process motivation and employee delight have to be controlled autonomously, so additives of effect may be extra expeditiously perceived and do not forget higher know-how. Herzberg's (1968) motivation-hygiene concept perceives natural sparks success, affirmation, the work itself, and hygiene elements, which tend to be intrinsic elements of social association, supervision, pay. Herzberg's view is that those motivations incite career delight 
because they satisfy man's necessity for self-acknowledgment (Maslow, 1954). As made by Porter and Lawler (1968), the expectancy concept argues that a remuneration execution structure affects task satisfaction (Ferris, 1977; Igalens \& Roussel, 1999). However, to encourage healthy employee motivation, garment industries need to grow task pleasure and watch humanitarian aid's proper implementation. Also, extant kinds of literature have proven that preceding studies are trusted auxiliary facts amassed thru literature surveys, secondary statistics, case reviews from specific nations, and many others. (Sarker \& Afroze, 2014). the suggests that a significant gap exists in the effect of employee motivation and activity pleasure on private business banks in Bangladesh. This study's paper's foremost objective is to measure the patron's delight towards motivational dimensions like intrinsic factors and extrinsic factors of motivation inside the banking industries in Bangladesh. The primary consciousness of this have a look at is to assess the employee's delight and employee's dedication in the direction of motivational elements of personal banking in Bangladesh. From these studies, the authority of banking sectors in Bangladesh will benefit from enhancing the motivational elements of banking sectors like intrinsic and extrinsic factors to increase employee pleasure and performance. Besides help, the outcomes may help all bank's administrators screen the prevailing scenario of motivational dimensions in their respective banks. The observe will also advise a few massive adaptable regulations and strategies for employee's delight and employees. Bangladesh's primary bank may also use some guidelines and strategies to enhance the banking industries' motivational elements.

\subsection{LITERATURE REVIEW OF THE STUDY}

This section presents the literature from the past research discussed in short based on modern studies' key fields. This bankruptcy mostly illustrates the four mechanisms used in this look - employee determination, employee satisfaction, factors implicit in it, and motivational factors from the outside. In Bangladesh, these systems in the private manufacturing sector are explored in detail. It is possibly verbal to analyze literature used as part of the composed artwork. Nevertheless, when using a specific position in full circumstances, ratings are made records. The stipend forms may be unambiguous, hypothetical, easy-to-diagnose, or methodological.

Secondly, it aims to reflect, procure, compare, handle, and solidify relevant reports with an indication of the literature assessment. The assessment of the literature assessment is planned within the equivalent vintage closeness of a thesis. This acknowledges the primary problem or idea essential to the exploration problem and analysis and offers a more straightforward interpretation of the theoretical structure to be composed later for the exam. This chapter begins with an analytical glance at the mostly based component that addresses the mediating assembly; this is the employee method's joy.

It then reflects on the inherent motivational and extrinsic motivational causes, which are unbiased variables. After that, this financial catastrophe offers details about the relationship between the four structures. The word "commitment" still has meaning in nearly every sphere of our lives. So how, without the business climate, can it remain? It supports all inspiration (movements to help employees work more efficiently) and self-motivation or encouragement (getting people to encourage themselves) "employee attempt to obtain organizational dreams. It embraces both motivation (movements to make people work extra efficaciously) and self-motivation or empowerment (getting human beings to inspire themselves) "employee attempt to attain organizational dreams. (Holden 1998). "employee dedication is the loyalty and aid of the body of employees to the dreams of the corporation" (start, 1997). It is an intellectual attachment felt by the company's labor force (O'Reily \& Chatman, 1986). A person emphasizes his/her loyalty and involvement in the company closest to the employer (Robbins, \& Coutler, 1999). Employee commitment was described by Greenberg and Baron (2000) as the extent to which an employee recognizes and is engaged or reluctant to leave his employer. There are three stylish subjects of employee willpower in the workplace: Affective engagement-the emotional \& psychological attachment and involvement of employees within the enterprise; Continuing dedication-a continuation of employment inspired by the useful resource of expenses and benefits associated with leaving the employer of the commercial enterprise, and normative determination-obligatory determination

A clear inference is taken into account as the maximum best for a corporation of the three forms as mentioned earlier of commitment, as workers with excessive stages of affective involvement are far more likely to willingly commit to the corporate standard's general success and efficiency, or maybe do more than they are supposed to do. The value of employee involvement within the company has been recognized around the globe for the long term.

In reality, an organization's effectiveness depends on the commitment of its employees; the more dedicated the staff, the greater the agency's overall average results (Holden, 1998; Shore, \& Martin, 1989; Meyer, Paunonen, Gellaty, Goffin, \& Jackson, 1989; Meyer, Allen, \& Smith, 1993; Meyer, Stanley, Herscovitch, \& Topolnytsky, 2002; Siders, George, \& Dharwadkar, 2001; Jaramillo, Mulki, \& Marshall, 2005).

Employee engagement is the critical detail that determines the fulfillment of an employer in the modern international organization of today because an employer needs to have professional, reliable, and dedicated human belongings in order to maintain its aggressive market function in the state of affairs of increasing 
competition and constant technological improvements (Feldman, \& Moore, 1982). Simultaneously, employee paintings' quality, enjoyment, and productivity remain the main contributing factors to the company's success, and employee engagement is regarded as the primary driver for improving fine and productivity (Denton, 1987).

Employment joy is primarily how human beings, mainly, since their occupations and separate elements in their vocations. It is miles about how individuals prefer their occupations to a first-rate offer (pride) or (dissatisfaction) (Spector, 2000). This derives high-quality and organizational viewpoints that reflect job delight, while low and predictive impressions indicate unhappiness with artwork in the field's direction. As the Armstrong (2010) resource demonstrates, confirmation is often portrayed as proportionate to paintings' pride. Pastime enjoyment is also a sensation that seems to be due to the assumption that the job allows material and mental needs to be fulfilled (Aziri, 2008). What human beings choose to do is also known as motivation. The motivation and motivation of the term refer to the desires, fears, and aspirations of people that motivate them to act as they do at present (Walker \& Miller, 2010). Human beings motivated by magnificent challenge pleasure measures, as confirmed by Brookfield (2007), may have an additional useful body and intellectual data that can lead to improved productivity and amplitude in their career execution and may stay longer in tubulation.Besides, he believes that career delight is one factor or clarification in employee goals to leave the motivation (a charge, 2011). In this way, the delight of technique will decide the specialist's inspiration and intent to live or abandon the association. The analysis further advises that the employee's pride requires estimates: intrinsic and extrinsic. Motivations can help produce the delight of the agent's employees and enhance their execution within the workplace.

Ryan and Deci (2000a) concluded that the period of unessential basis means the initiation of an advancement that recalls the real purpose of achieving such separable outcomes and, as a result, appears explicitly about motivation, which shows doing a hobby for the operation its elf's natural delight. When using specific strategies, the primary source of motivation or volitional change is not always the inherent motivation; besides, it is an inevitable and key one (Robbins, 2003). Functional thinking is based solely on the need for trust and opportunity (Tamanna, 2010). As a result, do not forget to use the winning exam to depict a usually impelled start for paintings as the entity may be called upon to understand even if the entity severed the company's knowledge. Islam et al. (2014), a pioneer in intrinsic and external motivation, performed an examination that was forced to choose the effects of extrinsic incentives on work motivation with study office evaluations and one vicinity search. In line with Mustapha (2013), intrinsic motivators and extrinsic hygiene components have been influenced by employee interaction with pastime joy and staff determination. Being driven can be described as something going to do (Deci and Ryan, 2000). A virtual character is encouraged and energized to step in the direction of a surrender (Deci and Ryan 2000). Limitless ideas are superior in order to have a basis for inspiration. One general definition of motivation, drawn from (Deci \& Ryan 2010), suggests possible sea splendor motivators: intrinsic and extrinsic. Although the preceding chapter emphasizes internal factors, this section distinguishes external variables. This process focuses on extrinsic aspects, whereas the last portion was subject to intrinsic influences. Extrinsic motivation can be defined as doing something because it leads to a different result (Deci and Ryan 2000). This means that, instead of the job's actual satisfaction, additional encouragement or rewards are gained by performing a task. A key motivator for determining whether to enroll with an employer in job assessment is extrinsic incentives, primarily cash and salary returns (Rynes, Gerhart, and Minette 2004).

Money and payment are not the only extrinsic awards that an employee may also receive from the action, though profit is one of the most significant variables in someone's decision to accept or reject an activity request, together with previous research (Rynes et al., 1992). Some argue that operation protection, type of work, growth potential, business characteristics, and pay are only a few of those weighed in every decision (Jurgensen 1978, judge and Bretz 1992). Judge and Bretz (1992) noted that one of the essential operational characteristics central to a decision-making method is merchandising possibilities. Three elements of the pinnacle have incentives, hours, and pay in a look at the last 30 years. While the incentives and hours rated higher, the importance of compensation seemed to improve (Jurgensen 1978). In a more recent study, extrinsic rewards were described as pay, inventory alternatives, concessions, value sharing, promotions, and benefits (Cummings and Worley 20015).

\section{Research Framework}

Based on the literature review, the following research framework is developed. 


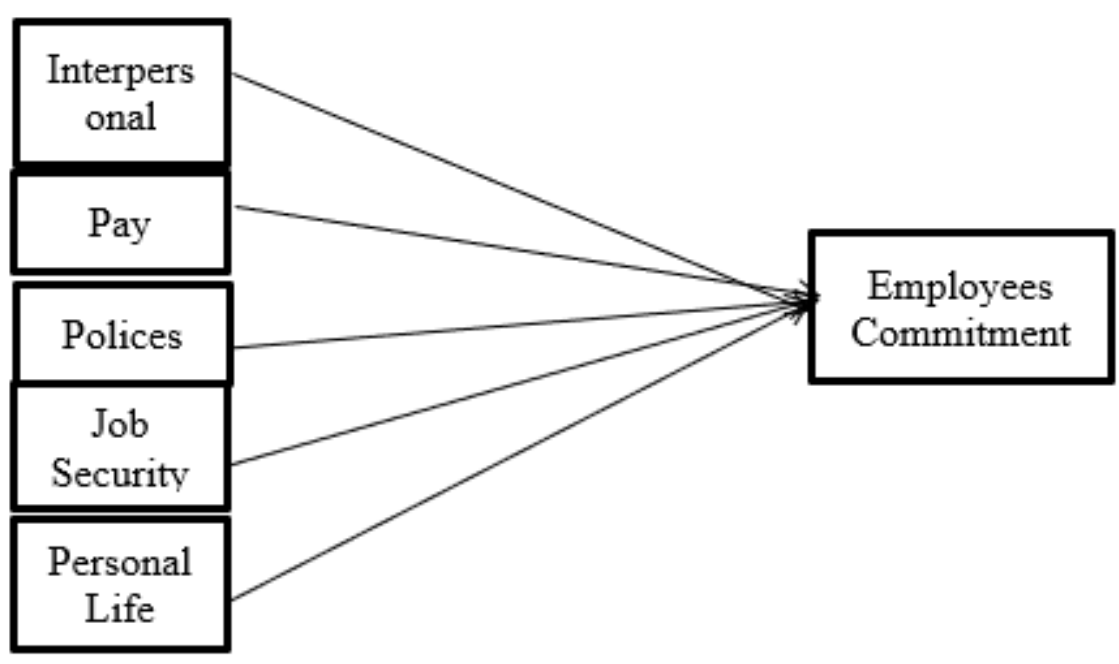

Figure 2.1 Hypothesised Model of the Study

\subsection{Method of the study}

As the study supports exploring the factors influencing consumers' intention to buy foreign merchandise, especially targeting buyers of Bangladeshi industrial banks, it is essential to look at collecting data from collected is a perfect illustration of the specific position population of Bangladesh. Via the dissemination of selfadministered questionnaires, the information needed for the review was obtained. Based primarily on the literature evaluation, all the items were created. The questionnaire was translated into English, and later it changed into Bengali with the aid of a competent translator. The central aim of solving the issues in Bengali is to make it practical for respondents to understand the issues as they should be and address them. Two hundred ten respondents retested the respondents' products. Any objects have been rephrased, and from the very last edition of the questionnaire, some things have been omitted. Cronbach's alpha takes a look at translated into finished for reliability assessment. The extreme reliability of the questionnaire is demonstrated by an alpha charge of .820 . For this cause, the study's findings indicated that the questionnaire's questions were accurate and valid, stating that the questionnaire should be used for the authentic look to accumulate knowledge. The respondents have been 210 to perform such research, as indicated via Hair et al. (2009). Besides, Sekaran (2003) observed that the optimal sample size is a sample size composed of more than 30 members for most research projects, but less than 500 .

Consequently, the test's pattern duration is 260 under this particular law (specific information distribution is supplied in table 1). Fifty questionnaires were removed for the examination since they were no longer completed by the respondents, resulting in 210 questionnaires for statistical analysis. Thus, since the pattern size is larger than 2 hundred, this justifies the sample length used in this look. Descriptive assessment and validity testing by exploratory aspect analysis (EFA) was changed to SPSS at the initial stage. In conjunction with Hair et al. (2009), EFA activity is essential because it helps researchers summarise the data collected from a particular collection of documents. Later, to validate the calculation model, SEM was run through AMOS, and finally, the assessment was completed by checking the overall structural model and confirming the hypotheses extracted for the exam.

\subsection{RESULTS AND DISCUSSION}

Exploratory factor analysis (EFA):

Hair et al. (2009) quantified that it is essential to perform a measured analysis since it allows researchers to condense the data obtained from a particular knowledge arrangement. Before proceeding with the EFA, two checks, to be precise, Kaiser-Meyer-Olkin (KMO) and Bartlett's sphericity test, should be checked by testing the fact ability of the details (Pallant, 2007). B. Tabachnick, L. Fidell, and S. Osterlind (2001) has shown that the estimation of the Preliminary Test (KMO) varies from 0 to 1 and, for careful analysis, it is essential to provide no less than the approximation of 0.6. And for Bartlett's Sphericity Measure, it is essential to obtain crucial $\mathrm{p}$ esteem $(\mathrm{p}<.05)$. We observed that both of these particular studies with the SPSS had an outstanding variety of results. Table 3 demonstrates the effects of this. The EFA identified 24 objects, and each considered necessary (over 0.50) 24 objects (Hair et al., 2009). It reveals that four divisions account for approximately 21 percent of the variance and that the overall variance was approximately 72.42 percent, which is extremely acceptable. When four pieces are kept, a more substantial shift is explained. Besides, Cronbach's alpha was calculated for each of the four variables. It can be shown that all things under all variables are accurate, as they have all outperformed the base estimate of .60 suggested by J.F. Skin, W.C. Dark, W.J. Babin, R.E. Anderson's (2010). 
Table-01: Kaiser-Meyer-Olkin (KMO) \& Barlett's test, authors'

Kaiser-Meyer-Olkin Measure of sampling Adequacy. $\quad .824$

$\begin{array}{lll}\text { Bartlett's Test of Sphericity } & \text { Approx.Chi-Squire } & 4437.148\end{array}$

Sig. $\quad .000$

Table 2. Exploratory Factor Analysis (EFA)

\begin{tabular}{|c|c|c|c|c|c|c|}
\hline FACTORS & IP & PY & PL & JS & PEL & EC \\
\hline IP1 & .755 & & & & & \\
\hline IP2 & .810 & & & & & \\
\hline IP3 & .820 & & & & & \\
\hline IP4 & .726 & & & & & \\
\hline PY1 & & .812 & & & & \\
\hline PY2 & & .758 & & & & \\
\hline PY3 & & .723 & & & & \\
\hline PY4 & & .881 & & & & \\
\hline PL1 & & & .739 & & & \\
\hline PL2 & & & .605 & & & \\
\hline PL3 & & & .702 & & & \\
\hline PL4 & & & .594 & & & \\
\hline JS1 & & & & .932 & & \\
\hline JS2 & & & & .803 & & \\
\hline JS3 & & & & .702 & & \\
\hline JS4 & & & & .653 & & \\
\hline PEL1 & & & & & .635 & \\
\hline PEL2 & & & & & .801 & \\
\hline PEL3 & & & & & .703 & \\
\hline PEL4 & & & & & .993 & \\
\hline EC1 & & & & & & .835 \\
\hline $\mathrm{EC} 2$ & & & & & & .501 \\
\hline EC3 & & & & & & .703 \\
\hline EC4 & & & & & & .793 \\
\hline
\end{tabular}

Evaluation of the Structural Equation Model. The model's aftereffect revealed that the model is sufficient as it has the required qualities for each of the records: root means square error approximation (RMSEA) $=.073$, comparative fit list $(\mathrm{CFI})=.901$. Normed X2 $=2.264$ (Figure2).

Results of Hypothesis Testing. As appeared in Table 5, The $p$ value $<.05$ was seen by all five theorized processes. Interpersonal variables have an immense effect on employee participation in Bangladesh's commercial banks, showing that the uniform regression weight of $\mathrm{H} 1=.354$, standard error $=.105$, vital ratio $=$ 2.547 , regression weight significance level $=$ significant at .013 . H2 was also recognized, suggesting that payment variables have an immense effect on employee participation in commercial banks in Bangladesh, such as the uniform regression weight $=.475$, standard error $=.087$, vital ratio $=4.234$, and regression weight significance level $=.008$. H3 The uniform regression weight $=.347$, standard error $=.147$, critical ratio $=2.414$, and regression weight importance level $=.000$ were also sponsored as H3. Thus, $\mathrm{H} 3$ has also been recognized, demonstrating that the organization's policy significantly influences employee involvement in commercial banks in Bangladesh, such as the uniform regression weight $=.375$, standard error $=.079$, critical ratio $=4.124$, and regression weight significance rating $=.008$. $\mathrm{H} 4$ has also been recognized, demonstrating that job stability significantly affects employee participation in commercial banks in Bangladesh. The standardised regression weight $=.375$, standard error $=.097$, critical ratio $=4.324$, and the level of significance for regression weight $=.007$. $\mathrm{H} 4$ has likewise been acknowledged, showing that work stability significantly affects employee involvement in Bangladesh's commercial banks, such as the uniform regression weight $=.375$, standard error $=.097$, vital ratio $=4.324$ regression weight significance level $=.007 . \mathrm{H} 5$ was also recognized, showing that personal life significantly affects Bangladesh's commercial banks' employee involvement, as the standardized regression weight $=.487$, standard error $=.097$, vital ratio $=4.244$, and regression weight significance level $=.009$. 
Table-3: Fitness Assessment of the Structural Model.

\begin{tabular}{llll}
\hline Name of Category & Required Value & $\begin{array}{l}\text { Obtained } \\
\text { Value }\end{array}$ & Comments \\
\hline Absolute fit & RMSEA $<0.08$ & 0.073 & $\begin{array}{l}\text { The required value is attained } \\
\text { Incremental fit }\end{array}$ \\
\hline Parsimonious fit & CFI $>0.90$ & 0.901 & The required value is attained \\
\hline Cour $<3-5$ & 2.264 & The required value is attained \\
\hline
\end{tabular}

Source: Byrne (2010); Hair, Black, Babin, and Anderson (2010); Kline (2011); Haque et al. (2013);

Zainudin (2012).

Note: RMSEA = root mean square error approximation; GFI = goodness-of-fit index; CFI = comparative

fit index.

Validity testing. Alongside the baseline model and the baseline model, in order to assess validity, the analysis has to include the general prediction model. It is essential to test convergent, discriminant, and facing validity to affirm the validity. Convergent validity is shown by the plurality of element loadings for each component (more than .70), average chi-square value (more than .50), and construct validity (also more than .50). On the other hand, discriminant validity is verified with the favorable comparison of the AVE and squared correlation ( $\mathrm{r} 2$ ). Here, in all the cases, AVE is more significant than the squared multiple correlation values, and this gives evidence of uniqueness for each construct. Also, theoretical support from literature proves the face validity of the constructs

Table 4. Validity Testing, authors'

\begin{tabular}{|l|l|l|l|}
\hline Construct & Cronbach's Alpha & CR & AVE \\
\hline Interpersonal & 0.714 & 5.247 & .444 \\
\hline Pay & 0.842 & 4.348 & .435 \\
\hline Policies & 0.757 & 5.457 & .447 \\
\hline Job Security & 0.865 & 4.224 & .578 \\
\hline Personal Life & 0.7451 & 4.214 & .4751 \\
\hline Employees Commitment & 0.8417 & 5.142 & .4175 \\
\hline
\end{tabular}

Table 5. Results of hypotheses testing, authors'

\begin{tabular}{|l|l|l|l|l|l|l|}
\hline & & & Estimate & S.E. & C.R. & P \\
\hline Employees Commitment & $<---$ & Interpersonal (IP) & 0.369 & .107 & 2.457 & .013 \\
\hline Employees Commitment & $<---$ & Pay (PY) & 0.475 & .087 & 2.234 & .000 \\
\hline Employees Commitment & $<---$ & Policies (PL) & 0.347 & .147 & 2.414 & .000 \\
\hline Employees Commitment & $<---$ & Job Security (JS) & 0.321 & .104 & 2.142 & .001 \\
\hline Employees Commitment & $<---$ & Personal Life (PL) & 0.451 & .086 & 2.541 & .015 \\
\hline
\end{tabular}

\subsection{CONCLUSION}

It is evident from the above discussions on the impartial variables (job protection, compensation, personal life, interpersonal, policies) that all the unbiased variables correlate with the dependent variable; nevertheless, the workers' engagement has the most robust coefficient correlation. However, loyalty and happiness alone would not be adequate, and thus, any time management needs to beautify dedication, all the various considerations must be considered. The study results prompted the development of extrinsic motivational variables and interpersonal, compensation, laws, operation security, and personal life to increase employees' motivational contribution. Because the cause is extensively related to workers' devotion, efforts must be made by financial institution employees to increase the degrees of those variables. The study results showed that credibility could be strengthened by appreciating verbal and written (citations) and meaningful benefits. It was echoed in the workers' recommendations that respect and reputation (both pay and security) could significantly affect their contribution to the workplace, such as private commercial banks in Bangladesh.

Provided that burden coincides with all the variables studied, control must take extrinsic steps to ensure the mission's pride. In any respect of vantage variables, security detectors must be fixed. Besides, broken operating equipment needs to be quickly restored. Supervision must still be strengthened but no longer used as an avenue to resolve personal scores with managers. These studies have demonstrated that step-forward management and job joy will appreciate human capital's overall motivation within the financial institution. Consequently, efficiency may be higher, giving the financial institution the capacity to survive the industry's competitive environment. It is widely recommended that job conditions continue to focus at the bank for studies on improving human properties. 


\section{REFERENCES:}

al-Attas, S. M. N. (2014). Prolegomena to the Metaphysics of Islam. Penerbit UTM Press.

Anderson Jr, J. D. (2010). Fundamentals of aerodynamics. Tata McGraw-Hill Education.

Appel, A. E., \& Holden, G. W. (1998). The co-occurrence of spouse and physical child abuse: a review and appraisal. Journal of family psychology, 12(4), 578.

Armstrong, C. S., Barth, M. E., Jagolinzer, A. D., \& Riedl, E. J. (2010). Market reaction to the adoption of IFRS in Europe. The accounting review, 85(1), 31-61.

Awang, Z. (2012). Structural equation modeling using AMOS graphic. Penerbit Universiti Teknologi MARA.

Aziri, B. (2011). JOB SATISFACTION: A LITERATURE REVIEW. Management Research \& Practice, 3(4).

Bartelsman, E., Scarpetta, S., \& Schivardi, F. (2005). Comparative analysis of firm demographics and survival: evidence from micro-level sources in OECD countries. Industrial and corporate change, 14(3), 365-391.

Blankenberg, F. G., Katsikis, P. D., Tait, J. F., Davis, R. E., Naumovski, L., Ohtsuki, K., ... \& Maecker, H. T. (1998). In vivo detection and imaging of phosphatidylserine expression during programmed cell death. Proceedings of the National Academy of Sciences, 95(11), 6349-6354.

Blau, G., \& Boal, K. (1989). Using job involvement and organisational commitment interactively to predict turnover. Journal of management, 15(1), 115-127.

Brookfield, H., \& Parsons, H. (2007). Family farms: survival and prospect: A worldwide analysis. Routledge.

Col, N. F., Surks, M. I., \& Daniels, G. H. (2004). Subclinical thyroid disease: clinical applications. Jama, 291(2), 239-243.

Cooper, S. E., \& Lowman, R. L. (2018). Ethical issues in psychological consultation.

Crespo, A., Bellot, M. M., Chabak, K. D., Gillespie, J. K., Jessen, G. H., Miller, V., ... \& Smith, H. E. (2009). High-power Ka-band performance of AlInN/GaN HEMT with 9.8-nm-thin barrier. IEEE Electron Device Letters, 31(1), 2-4.

Dunham, R. B., Grube, J. A., \& Castaneda, M. B. (1994). Organisational commitment: The utility of an integrative definition. Journal of Applied psychology, 79(3), 370.

Ferris, S. D., \& Whitt, G. S. (1977). Loss of duplicate gene expression after polyploidisation. Nature, 265(5591), 258.

Greenberg, J., \& Baron, R. (2004). A. 2000. Behavior In Organization. A Pearson Education Company.

Hair, J. F., Black, W. C., Babin, B. J., Anderson, R. E., \& Tatham, R. L. (2009). Análise multivariada de dados. Bookman Editora.

Heneman, R. L., Greenberger, D. B., \& Strasser, S. (1988). The relationship between pay-for-performance perceptions and pay satisfaction. Personnel Psychology, 41(4), 745-759.

Herzberg, F. (1968). One more time: How do you motivate employees.

Igalens, J., \& Roussel, P. (1999). A study of the relationships between compensation package, work motivation and job satisfaction. Journal of organisational behavior, 20(7), 1003-1025.

Innocenti, L., Peluso, A. M., \& Pilati, M. (2012). The interplay between H.R. practices and perceived behavioural integrity in determining positive employee outcomes. Journal of Change Management, 12(4), 399-415.

Islam, M. N., Zhang, M., Adhikari, B., Xinfeng, C., \& Xu, B. G. (2014). The effect of ultrasound-assisted immersion freezing on selected physicochemical properties of mushrooms. International Journal of Refrigeration, 42, 121-133.

Jaramillo, F., Mulki, J. P., \& Marshall, G. W. (2005). A meta-analysis of the relationship between organisational commitment and salesperson job performance: 25 years of research. Journal of Business Research, 58(6), 705-714.

Judge, T. A., \& Bretz, R. D. (1992). Effects of work values on job choice decisions. Journal of applied psychology, 77(3), 261.

Komlósi, E., \& Obermayer-Kovács, N. D. (2014). What Emotional Intelligent Traits Enable Managers to Share Knowledge for Work-Related Quality of Life?. In Human Capital without Borders: Knowledge and Learning for Quality of Life; Proceedings of the Management, Knowledge and Learning International Conference 2014 (pp. 325-333). ToKnowPress.

Maslow, A. H. (1954). The instinctoid nature of basic needs. Journal of Personality.

Massey, D. S., \& Denton, N. A. (1987). Trends in the residential segregation of Blacks, Hispanics, and Asians: 1970-1980. American sociological review, 802-825.

Meyer, J. P., \& Allen, N. J. (1991). A three-component conceptualisation of organisational commitment. Human resource management review, 1(1), 61-89.

Meyer, J. P., Allen, N. J., \& Smith, C. A. (1993). Commitment to organisations and occupations: Extension and test of a three-component conceptualisation. Journal of applied psychology, 78(4), 538.

Meyer, J. P., Paunonen, S. V., Gellatly, I. R., Goffin, R. D., \& Jackson, D. N. (1989). Organisational commitment and job performance: It's the nature of the commitment that counts. Journal of applied 
Psychology, 74(1), 152.

Meyer, J. P., Paunonen, S. V., Gellatly, I. R., Goffin, R. D., \& Jackson, D. N. (1989). Organisational commitment and job performance: It's the nature of the commitment that counts. Journal of applied Psychology, 74(1), 152.

Meyer, J. P., Paunonen, S. V., Gellatly, I. R., Goffin, R. D., \& Jackson, D. N. (1989). Organisational commitment and job performance: It's the nature of the commitment that counts. Journal of applied Psychology, 74(1), 152.

Meyer, J. P., Stanley, D. J., Herscovitch, L., \& Topolnytsky, L. (2002). Affective, continuance, and normative commitment to the organisation: A meta-analysis of antecedents, correlates, and consequences. Journal of vocational behavior, 61(1), 20-52.

Mohsan, F., Nawaz, M. M., Khan, M. S., Shaukat, Z., \& Aslam, N. (2011). Are employee motivation, commitment and job involvement inter-related: Evidence from banking sector of Pakistan. International Journal of Business and Social Science, 2(17).

Mustapha, A., Aris, A. Z., Juahir, H., Ramli, M. F., \& Kura, N. U. (2013). River water quality assessment using environmentric techniques: case study of Jakara River Basin. Environmental Science and Pollution Research, 20(8), 5630-5644.

O'Reilly, C. A., \& Chatman, J. (1986). Organisational commitment and psychological attachment: The effects of compliance, identification, and internalisation on prosocial behavior. Journal of applied psychology, 71(3), 492.

Pallant, J., \& Manual, S. S. (2007). A step by step guide to data analysis using SPSS for windows. In SPSS Survival Manual. Open University Press.

Payan, J. M., Svensson, G., Awuah, G., Andersson, S., \& Hair, J. (2010). A "cross-cultural RELQUAL-scale" in supplier-distributor relationships of Sweden and the USA. International Marketing Review, 27(5), 541-561.

Porter, L. W., \& Lawler, E. E. (1968). Managerial attitudes and performance.

Price, S. C., Stuart, A. C., Yang, L., Zhou, H., \& You, W. (2011). Fluorine substituted conjugated polymer of medium band gap yields 7\% efficiency in polymer- fullerene solar cells. Journal of the American Chemical Society, 133(12), 4625-4631.

Randolph-Seng, B., Cogliser, C. C., Randolph, A. F., Scandura, T. A., Miller, C. D., \& Smith-Genthôs, R. (2016). Diversity in leadership: race in leader-member exchanges. Leadership \& Organization Development Journal, 37(6), 750-773.

Robbins, R. J. (2003). Phenolic acids in foods: an overview of analytical methodology. Journal of agricultural and food chemistry, 51(10), 2866-2887.

Robbins, S. P., \& Coulter, M. (2007). Principles of management. Translated by Seyyed Mohammad Arabi and Mohammed Ali Hamid Rafiee and Behrouz Asrari Ershad, Fourth Edition, Tehran: Office of Cultural Studies.

Ryan, R. M., \& Deci, E. L. (2000). Intrinsic and extrinsic motivations: Classic definitions and new directions. Contemporary educational psychology, 25(1), 54-67.

Rynes, S. L., Gerhart, B., \& Minette, K. A. (2004). The importance of pay in employee motivation: Discrepancies between what people say and what they do. Human Resource Management: Published in Cooperation with the School of Business Administration, The University of Michigan and in alliance with the Society of Human Resources Management, 43(4), 381-394.

Saks, A. M. (2006). Antecedents and consequences of employee engagement. Journal of managerial psychology, 21(7), 600-619.

Sarker, M. A. R., \& Afroze, R. (2014). Can HRM practices improve job satisfaction of Ready Made Garment (RMG) employees in Bangladesh? An alternative solution to recent unrest. International Journal of Business and Management, 9(10), 185.

Sekaran, U., \& Bougie, R. (2003). Research Methods For Business, A Skill Building Approach, John Willey \& Sons. Inc. New York.

Shore, L. M., \& Martin, H. J. (1989). Job satisfaction and organisational commitment in relation to work performance and turnover intentions. Human relations, 42(7), 625-638.

Shore, L. M., \& Martin, H. J. (1989). Job satisfaction and organisational commitment in relation to work performance and turnover intentions. Human relations, 42(7), 625-638.

Siders, M. A., George, G., \& Dharwadkar, R. (2001). The relationship of internal and external commitment foci to objective job performance measures. Academy of Management Journal, 44(3), 570-579.

Spector, P. E., Zapf, D., Chen, P. Y., \& Frese, M. (2000). Why negative affectivity should not be controlled in job stress research: Don't throw out the baby with the bath water. Journal of Organizational Behavior, 21(1), 79-95.

Tabachnick, B. G., Fidell, L. S., \& Osterlind, S. J. (2001). Using multivariate. New York: Statistics.

Welte, K., Wang, C. Y., Mertelsmann, R., Venuta, S., Feldman, S. P., \& Moore, M. A. (1982). Purification of 
human interleukin 2 to apparent homogeneity and its molecular heterogeneity. Journal of Experimental Medicine, 156(2), 454-464.

Wrape, E. R., Callahan, J. L., Rieck, T., \& Watkins Jr, C. E. (2017). Attachment theory within clinical supervision: application of the conceptual to the empirical. Psychoanalytic Psychotherapy, 31(1), 37-54. 